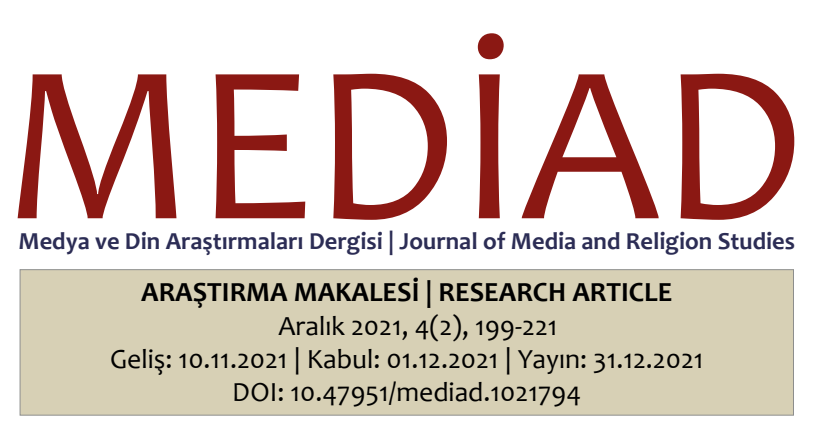

\title{
The Religious Framing Impact on Counterarguing Towards Vaccination Ads: Consideration of the Extended-ELM Perspective
}

\begin{abstract}
Mehmet Safa ÇAM*
Abstract

As the fluctuating effects of the pandemic continue, vaccination studies accelerated to ensure mass immunity. However, considering the speed of inoculation, it should be emphasized that it is evident of hesitancy threatening the achievement of herd immunity. The COVID-19 pandemic has deeply stirred up suspicions about many new habits in daily lives; therefore the vaccination has no exception. This paper is dedicated to examining communication framings designed to promote vaccination programs, as it might be a communicative remedy of counter-responses against the vaccination. Yet, a great deal is unexplored how the pandemic causes people to generate counterarguments against the vaccination program. Therefore, this study aimed to analyze which features of the communications lead to such a negative belief and investigate the effects of religious framing on vaccination attitudes, based on the fact that people take a religious perspective in crisis times. Findings by $2 \times 2 \times 2$ between-subjects design of ANCOVA revealed that selecting a framing path influences the general thought about vaccination, and religious-framed messages have the ability to transform counterarguing tendency. But these capabilities have some limitations and religious framing generally benefits through interaction with loss-framed messages. The theoretical contributions were mentioned following the results.
\end{abstract}

Keywords: Religious Framing, Extended-ELM, Absorption, Counterarguing, Message Unexpectedness

\section{Așı Mesajlarına Yönelik Karşı Argüman Gelișiminde Dini Çerçeveleme Etkisinin Genişletilmiş-ELM Modeli Üzerinden İncelenmesi}

Öz

Pandeminin etkileri dalgalanarak devam ederken, toplu bağışıklığın sağlanması için aşı çalışmaları da hız kazanmıştır. Ancak aşılama hızı ve aşılanma oranları dikkate alındığında, sürü bağışıklığının sağlanmasını tehdit eden tereddütlerin bulunduğu vurgulanmalıdır. COVID-19 salgını, günlük yaşamdaki birçok yeni alışkanlık hakkında derin şüpheler uyandırdı ve aşı da bu konuların başında gelmektedir. Bu makale, aşılamaya yönelik tepkilerin iletişimsel bir kapsamı olabileceğinden hareketle aşı programını teşvik etmek amacıyla tasarlanmış mesaj çerçevelerini incelemeye adanmıştır. Ancak, pandeminin bireylerin tedbirlere ve aşının kendisine yönelik olumsuz inançlar üretmesine neden olan pek çok faktör keşfedilmemiş durumdadır. Bu nedenle, mevcut çalışmanın amacı, kriz zamanlarında bireylerin dini bir yaklaşım sergiledikleri varsayımından hareketle, belirli iletişim yaklaşımlarını analiz etmek ve dini çerçevelemenin aşılama tutumları üzerindeki etkilerini araştırmaktır. 2×2×2 denekler-arası ANCOVA tasarımına ait bulgular, bir çerçeveleme koşulunu kullanmanın aşılama hakkındaki genel düşünceleri etkilediğini ve özellikle dini çerçeveli mesajların karşıt tepkileri dönüştürme yeteneğine sınırlı da olsa sahip olduğunu ve dini çerçevelemenin kayıp çerçeveli mesajlarla etkileşimli şekilde genel olarak fayda sağladığını ortaya koymuştur. Çalışmanın sonucunda sonuçların teorik katkıları tartışılmıştır.

Anahtar Kelimeler: Dini Çerçeveleme, Genişletilmiş-ELM, Mesaja Çekilme, Karşıt Tepki, Mesaj Beklenmedikliği

ATIF: Çam, M. S. (2021). The religious framing impact on counterarguing towards vaccination ads: Consideration of the extended-elm perspective. Medya ve Din Araştırmaları Dergisi (MEDiAD), 4(2), s. 199 -221.

* Assist. Prof. Dr., Aksaray University, msafacam@aksaray.edu.tr | orcid.org/0000-0001-6046-4585, Aksaray, Türkiye 


\section{Introduction}

Messages promoting health behaviors are widely used in all kinds of media (Randolph and Viswanath, 2004). During the rapid spread of the pandemic throughout the world, the amount of information about infectious diseases and preventive measures increased even more (Vraga and Jacobsen, 2020). Messages in different formats (PSAs, posts, articles, interviews, etc.), which were initially published to increase compliance with protective measures, have recently started to be designed within the scope of effective communication strategies to develop positive attitudes towards vaccines and to overcome vaccination hesitancy. However, similar to opposing behavior to engage in the measures due to pandemic fatigue (WHO, 2020), one might argue that there is an intimidating hesitation to the vaccine itself and vaccination campaign (Palm et al., 2021). Since the effectiveness of herd immunity depends on being inoculated by the majority of the society, it is of great importance to provide a favorable attitude toward the vaccination program through a massive communication campaign.

Disapproval of the message premises is the crucial drawback confronted during health communications (Cho and Salmon, 2007a; Dillard and Shen, 2005; Reynolds-Tylus, 2019). When people perceive a threat to their freedom, they feel psychological arousal such as getting angry, thinking negatively, and then counterarguing to the reliability of the message (Gollust and Cappella, 2014). Persuasive messages promoting health behaviors give rise to counter argumentation due to the perceived threat to freedom of choice (Akhtar et al., 2020; Reynolds-Tylus, 2019). When these emerging biases about health behaviors are associated with the vaccination program, the hesitation toward inoculation arises. This denial against vaccination is an issue of concern that directly threatens mass immunization which stands on the approval of the vaccine by the general public (Hobson-West, 2003).

Vaccination programs towards corona infection confronted a massive behavioral resistance in Turkey, as it is all around the world. Although there is an official obligation to get vaccinated, no legal regulations have been enacted against vaccination resistance in Turkey (Bozkurt, 2018). Anti-vaccine protesters who are organized through social media platforms seem determined to bring their regular activities to the agenda. Recently, vaccine opposers protested against the new coronavirus measures, testing, the use of masks, and the vaccination program (Murat et al., 2021). These events could be considered concrete reflections of the anti-vaccine movement in Turkey. A recent study revealed that the anti-vaccine movement could become a matter of serious concern in Turkey. According to June 2021 data, $16 \%$ of individuals who have not been inoculated until that date stated that they would not get vaccinated in any condition. $19 \%$ of them were hesitant to vaccination intention. Furthermore, $17 \%$ of these people do not consider the disease as a threat to the country (IPSOS, 2021). However, in pandemic conditions where new variants emerge, it becomes vital to prevent existing anti-vaccination trends and to increase vaccination rates during the fight against the Covid-19 virus (WHO, 2019). In this context, message strategies created by authorized institutions could have a key role in overcoming vaccination hesitancy (Palm et al., 2021; Peng et al., 2021).

During the fight against vaccination hesitancy, the individuals' beliefs and attitudes towards the vaccination program are shaped by effective message framing which refers to the context of the communication. In the Covid-19 period, numerous studies have been conducted examining the effectiveness of message framing over preventive measures and attitudes towards vaccination (e.g. Banker and Park, 2020; Borah, Hwang, and Hsu, 2021; Ceylan and Hayran, 2021). The pandemic-focused framing studies have mainly concentrated on formats derived from mainstream approaches like loss-gain framed styles (Deslatte, 2020; Kim et al., 2021). The examination of how different message framing styles improve both compliances with preventive measures and positive attitudes towards vaccination is considered to be of importance in terms of developing effective communication strategies. The contribution of this study to the existing message framing literature will be exploring the impact of religious framing on vaccine hesitancy and counterarguing to vaccination behavior. We will consider the religious framing effect through the emotional processing of the message within the scope of the Extended-ELM model (Slater and Rouner, 2002). Thus, the current paper aims to contribute to the gap in the field of pandemic and message framing literature by investigating the religious content as a driving power on vaccination attitudes. As far as we know, the prior literature has not focused on the religious framing effect with regards to vaccination hesitancy in the Covid-19 period. More precisely, this paper offers religious framing that might lead to various benefits in improving attitudes towards vaccination programs by comparing with well-known message framing methods. As part of this process, we will also look through the Extended-ELM model to better understand whether religious messages are subject to emotional processing and to see the framing effect on counter-argumentation. 


\section{An Overview of the Message Framing Literature}

The framing theory asserts that individuals assume messages to either potential gains or possible losses and that attitudes might be influenced by altering the way information is presented (Smith and Petty, 1996). The underlying rationale behind framing theory is the assumption of construing different meanings from messages, facts, or information when they are transmitted from a range of perspectives. Hence, "message framing refers to the process by which people develop a particular conceptualization of an issue or reorient their thinking about an issue" (Chong and Druckman, 2007, p.104).

Message framing preferences influence various health decisions by presenting the benefits of exposing the behavior (gain-frame) or the costs of resisting the action (loss-frame) (Gallagher and Updegraff, 2012). While the information of "wearing a mask can effectively block the spread of the virus through saliva" represents the gain-framed message, the message of "without a mask, you are likely to contract COVID-19" exemplifies the loss-framed (Peng et al., 2021). This way of alteration in conveying the health message could have an important role in persuading as it has been revealed by the researchers that message frames are more effective than one another in promoting desired health behaviors although the same message is transmitted (Rothman and Salovey, 1997). According to the research findings, messages showing potential gains are more effective in promoting health behaviors, whereas loss framing has a stronger persuasive impact in avoiding the potential losses (Lee and Aaker, 2004). As the rest of the literature in the field of health communications, message framing studies have revealed contradictory findings in promoting vaccination rates. Bigman, Cappella, and Hornik (2010) concluded that individuals who were exposed to gain-framed messages about the human papillomavirus vaccine (HPV) indicated more positive attitudes towards the vaccination programs. However, the prior study about HPV vaccination had explored that intentions to get vaccinated were higher in respondents with loss-framed information than with gain-framed messages, pointing out the impact of external or internal moderators (Gerend and Sias, 2009). In a recent experimental study, it was found that a narrative message with a loss-frame was more convincing for HPV vaccine intake (Kim, Lee, and Kong, 2020). Contrary to these findings, Borah and colleagues (2021) revealed that "participants in the loss frame condition did not indicate significantly favorable attitudes toward the vaccination and higher intention to get the COVID-19 vaccine compared to participants in the gain frame condition". Peng and his colleagues (2021) emphasize that there is no consensus on the issue of vaccination promotion and further studies are necessary to understand which framing is more persuasive in engaging in preventive behaviors and the vaccination programs.

Exploratory studies have focused on the relative effectiveness of message frames that cover the potential gains of adopting a behavior or possible losses of not involving in a promoted action (Palm et al., 2021). Considering the growing literature on framing effects for the pandemic vaccination hesitancy, it is of great importance to detail the communicative factors promoting vaccination uptake by fostering positive attitudes towards vaccination. Therefore, the current paper aims to contribute to the existing literature by examining the religious framing effect, an unconventional approach in vaccination promotion, on counterarguing against vaccination. In this respect, the researcher expected the religious presentation of the arguments would launch an emotional processing as well as cognitive responses to the framed message.

\section{Religious Framing and Emotional Processing}

Integrating powerful arguments with an unexpected framing of the message might be the way to benefit in building persuasive communication (Smith and Petty, 1996). Religious message framing could offer a strategy to create a powerful impact in communicating the challenging issues. As religion has been known to enable the search for meaning, "it is predicted that the use of religious framing in media channels would moderate mood-related outcomes" (Exline et al., 2005). Earlier studies have revealed that including sacred conceptualization into treatment-based messages could encourage desired objectives related to health behaviors (e.g. Cranney, 2017; Epstein, 2018). Religious involvement could ease social support which has been assumed to maintain a recovery or prevent an illness. Moreover, individuals who define themselves as of a religious orientation are prone to avoid hazardous health issues (Cherry et al., 2015; Cummings et al., 2003; Hughes et al., 2004).

Religious context serves to heal through a "sense of coherence and meaning", making individuals comprehend their motivations, and boosting the ability to deal with an illness (George, Larson, Koenig, and McCullough, 2000). In line with this, the religious context builds tight bonds with emotional responses toward specific events and individuals. Ben-Ze'ev (2000) suggested that religious faith might have several 
impacts on individuals' emotional intensity. First of all, every incident, no matter how worthless they are, always has meaning for religious people. Events that are believed to happen with the permission of God allow individuals to become more emotionally intensive. Second, deservingness refers to a spontaneous approval of life events that indicates the willpower of the creator, and religious people are prone to comply with the events seen underserved by unreligious individuals. Because deservingness is negatively linked to emotional intensity, unreligious people are often with increased emotionality. According to Ben-Ze'ev, nonreligious individuals perceive the suffering events like pandemics, accidents, or wars to be out of their control. Since religious people believe those events are the expression of the intention of God, controllability refers to enhanced emotional intensity for religious people.

Exline and colleagues (2005) reported that individuals who described their post-trauma experiences through religious framing showed emotional responses which lead, in turn, more positive shifts in their state of mind. A recent study revealed that religiosity can help individuals to interpret, comprehend and react to crisis threats and messages. In a focus group study, participants told that they get relaxed and feel hope after praying during a tornado (Lim et al., 2019). According to Emmons (2005, p. 235) "religion has always been a source of profound emotional experience", remarking that beliefs of the nature of God enable strong emotional responses and have a significant impact on mental health. Furthermore, religious faith among adolescents has been associated with higher levels of empathic inducement and perspectivetaking (Markstrom et al., 2010). Similarly, Giordano, Prosek, and Lankford (2014) conducted an empirical study exploring to what extent the religious perspective would predict empathic relationships, and they discovered that two key components of spirituality, purpose/meaning, and unifying interconnectedness, significantly predicted empathy among graduate students. Based on the extensive volume of empirical literature focusing on the importance of religion on the emotional, empathic, and perspective-taking issues, it can be assumed that religious framing coincides with the Extended-ELM (Slater and Rouner, 2002), the re-adapted form of the Elaboration Likelihood Model (Petty and Cacioppo, 1986) for emotional processing.

\section{Religious Framing, Extended-ELM, and Counterarguing}

The Elaboration Likelihood Model posits that "the quality of the arguments contained in a message has a greater impact on persuasion under conditions of high than low issue involvement" (Cacioppo and Petty, 1984, p. 674). When conditions - appeals, images, framing- stimulate individual's motivation and skills to involve in issue-relevant thinking, "the elaboration likelihood is said to be high" (Petty and Cacioppo, 1986, p. 128). Smith and Petty (1996) argued that message frames could influence the extent of message processing, focusing on the unexpectedness of the framing that fuels the elaboration. Therefore, individuals who are exposed to strong arguments with unexpected framing might engage in the influence of persuasive communications. At this point, it should be noted that unexpectedness refers to the perceptions toward the attempts that the individual is not familiar with; for instance, meeting a loss-frame when expecting a benefitframe, or facing a gain-frame when expecting a loss-frame.

Religiosity reflects a more authoritarian and conservative individualism than non-religious people, hence facilitating to comply with the society and taking notice of suggestions from a reputable source (Ragsdale and Durham, 1986). In this sense, the religious framing might capture the viewers' attention and get them involved in the messages. As mentioned earlier, during troublesome periods when spiritual feelings are intensified, just like the Covid-19 pandemic (Bentzen, 2020; Boguszewski et al., 2020), individuals are more inclined to respond to the messages under the influence of religious teachings (Waqas, 2021). For example, the religious framing can positively affect attitudes and behaviors towards vaccination in today's pandemic conditions, reflecting a future-oriented measure to overcome a health problem. If Individuals encounter a religious framing unexpectedly instead of an ordinary message frame that emphasizes the benefits of vaccine uptake or the potential risks of not being vaccinated delivered by an expert source, this coincidence may have the potential to transform attitudes towards vaccination programs. Religiously framed messages could be "unexpected" during these periods and a definite impact might be anticipated.

Extended-ELM (Slater and Rouner, 2002), on the other hand, focuses on the message engagement and emotional propensity through empathy and character identification which are the main processes a persuasive content should stimulate. Originated from processing the persuasive content of the narrative, Extended-ELM differentiates from the traditional elaboration likelihood model in terms of the distinction between central and peripheral processes which become ambiguous (Slater and Rouner, 2002). However, Naseri and Tamam (2012) characterized the use of religious content in advertisements as a peripheral cue, as it was not associated with the central features of the product or brand. In its essence, the Extended- 
ELM postulates the importance of the absorption into a narrative message which refers to involving in the emotional states through emphatic or identification process reducing counter argumentation towards the persuasive message (Moyer-Gusé and Nabi, 2010). The Extended-ELM assumed that the experience of absorption can increase positive cognitive responses towards the persuasive message as "absorption and emotions are incompatible with counterarguing" (De Graaf et al., 2009). The issue involvement concept which leads to "greater attention to message arguments depending on their quality" in the existing ELM was replaced with the absorption/engagement terms in the extended version of ELM (Slater and Rouner, 2002). Therefore, absorption as the most distinctive characteristic of Extended-ELM has a pioneering role in regulating beliefs and attitudes towards the promoted behavior.

Several implications suggest that religious framing and figurative use of sacred symbols positively influence the message absorption and attitudes towards the outcome. For example, Dotson and Hyatt (2000, p. 64) argue that "concrete religious symbols take on more significance to those with higher levels of religious dogmatism", stating that the appearance of the religious framing elements could induce favorable links in their minds. Additionally, individuals with a stronger religious view might improve their perceptions of source similarity, trustworthiness, and reduced skepticism, based on religious framing messages (Taylor et al., 2010) so that individuals become available to be absorbed by a message who generate a sense of familiarity (Briñol and Petty, 2009). Lumpkins (2010) stated that individuals would opt for a religiously-framed message in advertising content that triggers emotions, leads to more pleasure, and encourages a favorable attitude as a peripheral cue. Although experimental studies yielded contradictory findings (Naseri and Tamam, 2012) in testing the effect of religious framing on high and low issue involvement conditions, the main effect of exposure to a religious symbolism as a peripheral cue has been affirmed on behavioral intentions (Dotson and Hyatt, 2000; Lumpkins, 2010). Furthermore, religious faith is pertinent to counterintuitive descriptions as a common feature in almost all belief systems (Ozorak, 2005). The counterintuitive messages are readily recalled and refer to a stronger influence on retrieval than usual conceptual links which has no intuitive violations (Boyer and Ramble, 2001). As depicted in mentioned papers, these peripheral religious cues that play an important role in emotionality, source perceptions, and absorption into the message make it feasible to examine religious framing in terms of Extended ELM, regardless of whether the message has been constructed in a narrative or the argumentative design.

Extended-ELM suggests a message representation based on emotional responses, such as stories, to eliminate counterarguing, which is an overwhelming obstruction to persuasion in health communications (Slater and Rouner, 2002). Therefore, counterarguing refers to a thinking activity that could cause a denial towards a desired attitude or behavior, that is, individuals mostly withstand the powerful messages that threaten their preferences which they are deeply engaged (Rucker and Petty, 2004). The main reason for this resistance is involving critical thinking and detailed elaboration of the message (Moyer-Gusé and Nabi, 2010). Because it poses a serious complication to persuasive communications, the way to overcome counterargumentation is to stimulate strong emotional and cognitive responses through message design that is not perceived as a direct persuasion effort (Walter and Cohen, 2019). The narrative form of message might be considered as an ingenious convincing effort that reduces the tendency of reactance when transmitted as a hidden persuasive attempt (Green, 2006). When individuals are captured by the story plot, counterarguing towards the message is suppressed and a significant influence on attitudes and behaviors can be expected depending on the character involvement (Kreuter et al., 2007; Moyer-Gusé, 2008).

Experimental findings indicate an inverse association between absorption into the message and counter argumentation. For example, Moyer-Guse and Nabi (2010) found that immersing in a health message through identification and the empathic process would negatively influence counterarguing. Individuals who are more engaged in a story-based message can emotionally process the arguments about health behaviors and configure the general attitudes towards the desired outputs which leads to reduced counterarguing (Niederdeppe et al., 2012). Furthermore, the absorption into the message content generates a sense of flow towards the message, which boosts the believability of the information presented in the ad, followed by defeating the counterarguing inclination of the viewers (Krakow et al., 2018).

Taken together, it is clear that counterarguing is an obstacle that needs to be overcome in promoting health behaviors during the pandemic period. Considering the success of vaccination campaigns, where speculative misinformation often takes place, individual counterarguing which is the starting point of reactance to the corona vaccine has turned into a crucial obstacle to mass immunity. Counterarguing is a tendency to bias processing caused by individual beliefs, but a communicative issue as well. The current 
paper argues that religiously framed messages might be key variables in minimizing counter-argumentation towards vaccination. However, recent studies stated that religiosity - both as the degree of religious life and the message appeal - is far from supporting this hypothesis. For example, Landrum, Olshansky, and Richards (2021) found that the religious appeals in a message asserting the Flat Earth Ideology that shows integrity to a large body of sacred text was failed against evidence-based arguments and stimulated the disposition to counterargue than the evidence-based arguments. Further, individual level of religiosity was found to be negatively associated with vaccination intentions that are, individuals who have a lower degree of religiosity would likely adopt vaccine intake (Milligan et al., 2021). Similarly, Olagoke, Olagoke, and Hughes (2021, p. 76) stated that religious individuals are more prone to develop counterarguing about vaccination, highlighting that those individuals consider the crises as "An Act of God and perceive the events as unchangeable or unavoidable". Thus, higher levels of religiosity have been correlated with vaccine rejection by considering it as being ineffective (Callaghan et al., 2021). However, the current study assumes that the religious-framed message strategy will have an impact on anti-vaccine beliefs, contrary to prior research using religious content as a message appeal. It seems possible to strengthen this rationale by presenting the vaccination behavior based on rightful due and religious responsibility, together with the risk of infecting others. In other words, the purpose of this study is to investigate the impact of a religiously framed message, not only limited to the display of religious figures, on counter argumentation to the vaccination program. Therefore, in line with the literature reviewed above, the research question could be designed as follows:

RQ: To what extent individuals who were exposed to a religiously framed message;

(a) get absorbed into the message,

(b) generate empathetic emotionality,

(c) develop message believability,

(d) perceive the persuasive intent,

(e) comprehend unexpectedness of the message,

(f) shape behavioral attitudes and,

(g) reduce the counterarguing proneness compared to a loss-gain framed communications?

\section{METHOD}

This paper aimed to investigate the effects of communicating the vaccination campaign by religious framing in comparison to loss/gain-framed messages through the emotional processing viewpoint. Given the background, the framework provided by the Extended-ELM model was benefited and it was predicted that the religious context would reduce counterarguing. The study followed the rules described in the "Higher Education Institutions Scientific Research and Publication Ethics Directive" and was consented to by an ethical agreement acquired from Aksaray University Human Research Ethics Committee and carried out as stated by the guidelines of the Helsinki Declaration.

\section{The Research Participants}

The purposive sampling technique was used in the study. Also called judgment sampling, this method is the intentional selection of a respondent group owing to its properties. The rationale of the purposive sampling is to focus on individuals with representative features who might better contribute to understand the study findings (Etikan et al., 2016). Several reasons make it essential to move on to a young sample in the study. During the general course of the pandemic, younger people were reluctant in adapting the preventive measures due to the low rates of getting infected for a long time. Consequently, this mentality has pioneered young people to underestimate the pandemic severity. However, the pandemic began to seriously threaten younger individuals with the emergence of mutations. Besides, as of September 2021 in Turkey, educational institutions have been decided to reopen within the limits of pandemic measures. This decision resulted in rising in the mobility of young people across regions, especially with the beginning of higher education activities. Shortly after, according to the Ministry of Health's announced data in mid-October, there was an obvious increase in the rates of new cases among younger people. It was stated that the vaccination rates among university students were far behind the desired levels as incongruent with the expectations. This suggests that there is still a serious bias against vaccination among younger individuals. Therefore, the attitudes of university students towards the vaccination messages were measured by using a young sample within the study. 
Table 1. Mean Scores of Demographic Characteristics by Religiosity and Vaccination Willingness $(\mathrm{N}=378)$

\begin{tabular}{|c|c|c|c|c|c|}
\hline \multirow[t]{2}{*}{ Demographics } & \multirow[b]{2}{*}{$\mathrm{N}(\%)$} & \multicolumn{2}{|c|}{ Religious Level ${ }^{*}$} & \multicolumn{2}{|c|}{$\begin{array}{c}\text { Willingness to } \\
\text { Vaccination }\end{array}$} \\
\hline & & Mean (sd) & Sig. & Mean (sd) & Sig. \\
\hline Gender & & & 0.003 & & 0.056 \\
\hline Female & $243(64,3)$ & $3.22(0.79)$ & & $3.43(1.22)$ & \\
\hline Male & $135(35,7)$ & $3.12(1.02)$ & & $3.18(1.24)$ & \\
\hline Age & & & 0.512 & & 0.775 \\
\hline $17-19$ & 147 (38.9) & $3.17(0.93)$ & & $3.41(1.30)$ & \\
\hline $20-22$ & $142(37.6)$ & $3.24(0.93)$ & & $3.26(1.26)$ & \\
\hline $23-25$ & $89(23.6)$ & $3.09(0.73)$ & & $3.36(1.03)$ & \\
\hline Region & & & 0.001 & & 0.277 \\
\hline Marmara & $60(15.9)$ & $3.42(0.74)$ & & $3.28(1.31)$ & \\
\hline Aegean & $46(12.2)$ & $2.91(0.76)$ & & $3.12(1.32)$ & \\
\hline Mediterranean & $82(21.7)$ & $3.06(0.71)$ & & $3.52(1.04)$ & \\
\hline Southeast & $16(3.2)$ & $3.57(1.12)$ & & $3.28(1.51)$ & \\
\hline Eastern Anatolia & $8(2.1)$ & $2.84(0.78)$ & & $3.51(1.28)$ & \\
\hline Black Sea & $7(1.9)$ & $2.28(1.21)$ & & $2.42(0.67)$ & \\
\hline Central Anatolia & $159(41.0)$ & $3.24(0.96)$ & & $3.37(1.25$ & \\
\hline Family Income (TL) & & & 0.532 & & 0.017 \\
\hline $1500-3000$ & $98(25.9)$ & $3.24(0.76)$ & & $3.21(1.17)$ & \\
\hline $3000-5000$ & $139(36.8)$ & $3.19(0.91)$ & & $3.53(1.18)$ & \\
\hline $5000-7500$ & $100(26.5)$ & $3.14(0.89)$ & & $3.14(1.24)$ & \\
\hline $7500-10000$ & $41(10.8)$ & $3.12(1.06)$ & & $3.70(1.37)$ & \\
\hline Dose Intake & & & 0.000 & & 0.000 \\
\hline None & $11(2.9)$ & $2.59(0.74)$ & & $2.43(1.04)$ & \\
\hline Single & $30(7.9)$ & $3.82(0.84)$ & & $2.35(1.24)$ & \\
\hline Double & $337(89.2)$ & $3.14(3.14)$ & & $3.46(1.18)$ & \\
\hline
\end{tabular}

*The Median Split of Religiosity = 3.05, referring to a threshold between high and low levels.

Four hundred and five university students attended the experimental study. However, a total of three hundred and seventy-eight fully completed survey forms were included in the analysis after twenty-seven incomplete and incorrect answers were eliminated. Sixty-four percent of the subjects were female with the age of $17-25$. Almost half of the subjects were from the inner regions of the country (48,5\%) and the rest were from the coastline regions (49\%). $2 \%$ of those did not express any residential region. Sixty-three percent of respondents reported lower-income (1500-5000 TL) and thirty-five percent of them reported relatively higher income (5001-10000+ TL). The rest of the subjects declared no income level. Finally, the study sample also varied concerning their inoculation status and the eagerness degree to engage in the vaccination program. While the rate of those who received a double dose was $\% 89$, the rate of those who received a single dose was \%8. Three percent of the participants declared they had never been vaccinated. More than half of the subjects (54\%) stated that they were vaccinated when it was their turn. Forty-one percent stated that they got vaccinated due to possible restrictions they were likely exposed to. In addition, two percent of the participants stated that they did not consider getting vaccinated despite all the pressures, and three percent stated that they would not get vaccinated for a while because of a recently-infected status (Table 1).

\section{Material Design and Procedures}

The COVID-19 vaccination message was designed in three different framings (religious-framed $\mathrm{x}$ loss/ gain-framed) and respondents were randomly exposed to one of three conditions. All frames were developed using the actual information about the vaccination program provided by authorized state agencies. The religious-framed message elaborated that resisting vaccination means violating a rightful due of others and that following the measures including inoculation is an order of our religion. Alternatively, the gain-framed message outlined the benefits of engaging the COVID-19 vaccination campaign, such as herd immunity 
and preventing intensive care. In the message with the loss-frame, the possible health problems that unvaccinated individuals would face were depicted in the light of a didactic approach with a striking photo of an exemplar. All three of the message frames are designed as a pamphlet and are completely presented in Appendix 1. Contributors who were eager to participate in the research voluntarily were exposed to either religious-framed messages or loss/gain-framed pamphlets. No criteria, such as being vaccinated or not, were set for the research participants because the study aimed to measure the impact of the message framing on counterarguing. In this case, even if they were vaccinated reluctantly, it was a priority to acquire the actual thoughts of individuals about vaccination following exposure to message frames.

An online survey was administered during September-October, 2021. A total of four-hundred fifty undergraduates from Aksaray University were recruited as participants and randomly assigned to one of three conditions. The respondents were told that they would be taking part in a study on pandemic measures. Precisely, contributors were requested to provide their feelings and attitudes on preventive measures, particularly on vaccination intentions. Before being exposed to the experimental stimuli, the participants rated the items about their demographic characteristics, including religiosity level, whether they had been vaccinated, and their willingness to get vaccinated. Participants responded to items regarding the dependent variables following exposure to experimental stimuli.

\section{Research Instruments}

The study employed a measurement instrument derived from prior researches and modified to the present paper. The scale instrument had several items and consisted of two basic sections. The initial section contained the demographic information and items measuring religious levels, vaccination willingness, and status of the participants. The religious level was assessed with an abbreviated version of The Centrality of Religiosity Scale (CRS) developed by Huber and Huber (2012). The statements for the vaccination willingness of the subjects were developed by the researcher and requested to be rated on a four-item scale. Again, the participants were instructed to indicate their vaccination status by marking "none, single-dose or double-dose" options. The second part of the survey incorporated measures including emotional responses, message absorption, source believability, perceived persuasion intent, counterarguing, and behavioral intention statements.

The multi-item instrument was used to evaluate the eight concepts to be tested within this study. The three-item scale ( 1 = strongly disagree; 5 = strongly agree) to assess emotional responses towards message content particularly to the depicted character was adapted from the original 10-items identification scale by Cohen (2001) and the items which were considered to be compatible with the scope of this study were selected. The respondents rated three items of the transportation scale (Green and Brock, 2000) items to evaluate the extent to which they felt absorbed by the ad message. Afterward, the subjects responded to an abbreviated set of items from the Narrative Believability Scale (NBS) which was originally produced by Yale (2013) to measure the message believability. Next, participants replied to two-scale items anchored by strongly disagree/strongly agree to appraise their perceptions toward the message unexpectedness, adapted from Lane and Jacobson (1997). A four-item scale ( $1=$ strongly disagree; 5 = strongly agree) from Cotte, Coulter, and Moore (2005) was utilized to assess individuals' perceptions toward the persuasive intent of the message. Counterarguing proneness was evaluated by two 5-point Likert items "designed to tap into the participant's tendency to critically examine or disagree with the message" (Nabi et al., 2007). Finally, subjects filled out a two-item scale to rate their behavioral intentions.

The set of counter-arguing statements were acquired by conducting a preliminary study with forty subjects. Prior to the experimental study, participants were instructed to take part in a thought-listing task (Rucker and Petty, 2004) in which at least five items to be recorded related to their feelings (whether favorable or negative) about the vaccination program and the vaccine itself. During the assignment lasted for 15 minutes, respondents generated their ideas open-endedly. Rated by two experts, the eight statements with the highest scores were included in the counter-argumentation instrument to be assessed by the respondents prior to the experimental stimuli (see Table 2). 
Table 2. Means, standard deviations, and reliability coefficients for the items

$M \quad S D$

\section{Vaccination Status}

How many doses of Covid-19 vaccine did you get?
() Any
() I got 1 dose
( ) I got 2 doses

\section{Vaccination Willingness}

Which of the following describes your attitude towards vaccination?

( ) When it's my turn, I made an appointment immediately and got vaccinated.

( ) I was forced to get vaccinated due to the restrictions in public domains such as shopping malls, schools, public transportation

( ) Despite all the compulsions, I do not plan to get vaccinated.

( ) I will not be vaccinated for a while ( 6 months, 5 months, 4 months, etc.) because I have recently had Covid.

\section{Religiosity}

How often do you think about religious issues?

How often do you attend religious organizations (mosques, etc.)?

How often do you pray?

How often do you experience situations in which you feel that God is

directing your life?

$3.46 \quad 1.11$

$2.35 \quad 1.16$

$3.04 \quad 1.27$

$3.08 \quad 1.12$

$2.80 \quad 1.29$

\section{Counterarguments}

Counterargue 1

I think the vaccines produced for COVID-19 have been adequately

tested.

Counterargue_2

I think vaccination will cause other ailments.

$3.51 \quad 1.35$

Counterargue_3

I believe that there will be many problems due to vaccination in the future.

$3.34 \quad 1.13$

$2.86 \quad 1.44$

Counterargue 4

Covid-19 vaccines have already been produced, but they are now on the market for commercial purposes.

Counterargue_5

I believe the vaccination will end the pandemic.

Counterargue_6

Many people who get vaccinated also suffer from the disease or die. Counterargue_7

I think that there are global powers getting profit from the vaccine.

Counterargue 8

Being forced to get vaccinated is definitely means violating human

rights.

\section{Empathetic Emotionality}

I think I have a good understanding of the character.

While viewing the ad I could feel the emotions of the character.

While viewing the ad, I wanted character to succeed in achieving his or her goals.

\section{Absorption}

I was mentally involved in the message

I could easily picture the events taking place

I could picture myself in the scene shown in the pamphlet
$2.75 \quad 1.45$

0.75

$3.26 \quad 1.39$

$3.46 \quad 1.32$

$3.72 \quad 1.34$

$2.80 \quad 1.29$

$4.04 \quad 1.11$

$3.76 \quad 1.25$

$3.95 \quad 1.23$

$2.37 \quad 1.19$

$3.55 \quad 1.13$

$3.70 \quad 1.20$

\section{.75}




\section{Believability}

I believe this information could be true.

It was easy to follow the story from beginning to end.

The information presented in this story was consistent.

All of the facts in this story agreed with each other.

\section{Unexpectedness}

Explaining why to get vaccinated in the light of this information is something new for me.

We see these messages about vaccines very often.

\section{Perceived Persuasiveness}

I was annoyed by this pamphlet because the message seemed to be trying to inappropriately manage or control my decisions.

The way this ad tries to persuade people seems acceptable to me.

I think that this advertisement is fair

The ad was fair in what was said and shown.

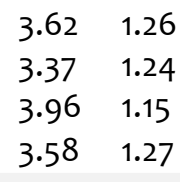

.81

$3.96 \quad 1.15$

1.27

$3.81 \quad 1.34$

$2.21 \quad 1.42$

.65

$\begin{array}{ll}3.71 & 1.37 \\ 4.08 & 1.11 \\ 3.38 & 1.34 \\ 3.37 & 1.39\end{array}$

\section{Results}

A 3 (religious framing vs. loss/gain framing) $\times 2$ (low vs. high religiosity) $\times 2$ (willingness vs. unwillingness to get vaccinated) between-subjects analysis of covariance (ANCOVA) was used to test the research hypotheses. The testing design examined the influence of these predictors on empathetic emotionality toward message characters, absorption, believability, unexpectedness, persuasiveness, and behavioral intentions. In the ANCOVA analysis, several demographic variables that are known to influence attitudes toward vaccination were also controlled, for example, the origin of residence would influence the overall attitudes toward the vaccination. Because the vaccination rates in coastal regions were completely higher than in the inner regions of the country. In addition, a similar control procedure was also performed on the gender, income level, religiosity, and willingness groups.

The analyses started with examining the correlations among interdependent variables to evaluate the predictive abilities of these variables. The calculations of the correlations were shown in Table 2. The results indicated moderate associations between the empathic emotionality towards the variety of framed ads, and the message absorption $(r=0.54)$ as well as between source credibility $(r=0.62)$. In addition, it was found that there was a robust bivariate link between being immersed in the message and the sense of unexpectedness $(r=0.87)$. Finally, as expected, the perceived persuasive intention and the proneness to counterargument scales demonstrated negative correlations with all other dependent variables.

Table 3. Correlation Matrix of the Variables with Reliability Coefficients

\begin{tabular}{|l|c|c|c|c|c|c|c|}
\hline & 1 & 2 & 3 & 4 & 5 & 6 & 7 \\
\hline 1. Emotionality & $(.81)$ & & & & & & \\
\hline 2. Absorption & $.54^{* *}$ & $(.80)$ & & & & & \\
\hline 3. Believability & $.62^{* *}$ & $.63^{* *}$ & $(.81)$ & & & & \\
\hline 4.Unexpectedness & .66 & $.87^{* *}$ & .01 & $(.65)$ & & & \\
\hline 5. Persuasiveness & $-.41^{* *}$ & $-.52^{* *}$ & $-.55^{* *}$ & $-.19^{* *}$ & $(.71)$ & & \\
\hline 6. Counterarguing & $-.21^{* *}$ & $-.12^{* *}$ & -.03 & $-.35^{* *}$ & .14 & $(.72)$ & \\
\hline 7. Behavioral Intent. & .81 & $.28^{* \pi}$ & $.31^{* *}$ & .06 & $-.21^{* *}$ & $-.16^{* *}$ & $(.89)$ \\
\hline
\end{tabular}

Cronbach's a reliability coefficients are shown in parentheses.

${ }^{* *}$ Correlation is significant at the 0.01 level (2-tailed).

Table 3 listed the means and standard deviations for the dependent variables caused by the conditions in the ANCOVA model. It is noticeable that framing conditions significantly affected most of the counter argumentations which are generated during the thought-listing task for the vaccination campaign. As a salient fact, it is noteworthy that a positive level of critical thinking was created in religious framing conditions than gain and loss framing conditions. Across the means of dependent variables, the scores calculated for the loss frame increased while the religious framing sustained its position ahead of gain framing. However, there was a clear achievement in favor of religious framing, especially in unexpectedness $(m=3.49, s d=1.20$, $\mathrm{p}<$.001), perceived persuasiveness $(\mathrm{m}=3.27, \mathrm{sd}=.81, \mathrm{p}<.001)$ and counterarguing $(\mathrm{m}=2.12, \mathrm{sd}=1.16, \mathrm{p}<.001)$ scores. Similarly, the religiosity category had mean scores in favor of strong sacred feelings on the dependent variables and counter-responses. Vaccination willingness has also mean scores which indicated that the 
demand for inoculation directly resulted in reduced counterarguments $(m=2.54, s d=1.17, p<.05)$, stronger emotionality $(m=4.77$, sd=.96, $p<.01)$ and message absorption $(m=3.41, s d=1.02, p<.05)$ (see Table 2$)$. The initial findings of the ANCOVA model explored that framing conditions significantly influenced and differentiated the mean scores among empathetic emotionality, absorption, unexpectedness, and counterarguing except believability, persuasiveness, and behavioral intentions when the descriptive constructs were controlled (Fig. 1). The impact of religious framing, particularly on message unexpectedness $(m=3.49, s d=.78, p=.001)$ and counterarguing $(m=2.13$, $s d=1.13, p<.001)$ was evident when the key demographic variables, vaccine willingness, and religiosity levels were controlled in ANCOVA analyzes.

Table 4. Group Statistics for the Dependent Variables by Framing Condition, Religiosity and Willingness

\begin{tabular}{|c|c|c|c|c|c|c|c|}
\hline & \multicolumn{3}{|c|}{ Framing Conditions } & \multicolumn{2}{|c|}{ Religiosity Level } & \multicolumn{2}{|c|}{ Vaccination Demand } \\
\hline & $\begin{array}{c}\text { Religious } \\
N=124\end{array}$ & $\begin{array}{l}\text { Gain } \\
N=134\end{array}$ & $\begin{array}{l}\text { Loss } \\
N=120\end{array}$ & $\begin{array}{c}\text { Low } \\
N=167\end{array}$ & $\begin{array}{l}\text { High } \\
N=211\end{array}$ & $\begin{array}{c}\text { Unwilling } \\
\mathrm{N}=208\end{array}$ & $\begin{array}{l}\text { Willing } \\
N=170\end{array}$ \\
\hline Counterargue_1 & $\begin{array}{c}2.86 \\
(1.33)^{* * *}\end{array}$ & $\begin{array}{c}3.11 \\
(1.27)^{* * *}\end{array}$ & $\begin{array}{c}2.40 \\
(1.16)^{* * *}\end{array}$ & $\begin{array}{c}2.41 \\
(1.18)^{* *}\end{array}$ & $\begin{array}{c}2.83 \\
(1.41)^{* *}\end{array}$ & $\begin{array}{c}2.81 \\
(1.27)\end{array}$ & $\begin{array}{c}2.78 \\
(1.32)\end{array}$ \\
\hline Counterargue_2 & $\begin{array}{c}3.35 \\
(1.44)\end{array}$ & $\begin{array}{c}3.49 \\
(1.34)\end{array}$ & $\begin{array}{l}3.68 \\
(1.23)\end{array}$ & $\begin{array}{l}2.60 \\
(1.18)\end{array}$ & $\begin{array}{c}2.77 \\
(1.18)\end{array}$ & $\begin{array}{c}3.95 \\
(1.19)^{* * *}\end{array}$ & $\begin{array}{c}3.14 \\
(1.35)^{* * *}\end{array}$ \\
\hline Counterargue_3 & $\begin{array}{c}3.13 \\
(1.50)^{*}\end{array}$ & $\begin{array}{c}3.28 \\
(1.36)^{*}\end{array}$ & $\begin{array}{c}3.63 \\
(1.39)^{*}\end{array}$ & $\begin{array}{c}2.89 \\
(1.23)\end{array}$ & $\begin{array}{c}2.73 \\
(1.33)\end{array}$ & $\begin{array}{c}3.81 \\
(1.28)\end{array}$ & $\begin{array}{c}2.95 \\
(1.43)\end{array}$ \\
\hline Counterargue_4 & $\begin{array}{c}2.59 \\
(1.44)^{* *}\end{array}$ & $\begin{array}{c}2.77 \\
(1.35)^{* *}\end{array}$ & $\begin{array}{c}3.25 \\
(1.45)^{* *}\end{array}$ & $\begin{array}{c}3.53 \\
(1.29)^{*}\end{array}$ & $\begin{array}{l}3.47 \\
(1.41)^{*}\end{array}$ & $\begin{array}{c}3.20 \\
(1.39)^{* * *}\end{array}$ & $\begin{array}{c}2.59 \\
(1.41)^{* * *}\end{array}$ \\
\hline Counterargue_5 & $\begin{array}{c}2.35 \\
(1.44)^{* * *}\end{array}$ & $\begin{array}{c}3.31 \\
(1.28)^{* * *}\end{array}$ & $\begin{array}{c}2.55 \\
(1.43)^{* * *}\end{array}$ & $\begin{array}{l}3.30 \\
(1.45)\end{array}$ & $\begin{array}{l}3.37 \\
(1.41)\end{array}$ & $\begin{array}{c}2.79 \\
(1.48)\end{array}$ & $\begin{array}{c}2.71 \\
(1.40)\end{array}$ \\
\hline Counterargue_6 & $\begin{array}{c}3.27 \\
(1.47)\end{array}$ & $\begin{array}{c}3.19 \\
(1.35)\end{array}$ & $\begin{array}{c}3.33 \\
(1.35)\end{array}$ & $\begin{array}{c}3.36 \\
(1.37)\end{array}$ & $\begin{array}{c}3.14 \\
(1.37)\end{array}$ & $\begin{array}{c}3.68 \\
(1.25)^{* * *}\end{array}$ & $\begin{array}{c}2.92 \\
(1.41)^{* * *}\end{array}$ \\
\hline Counterargue_7 & $\begin{array}{c}3.25 \\
(1.46)^{* *}\end{array}$ & $\begin{array}{c}3.35 \\
(1.28)^{* *}\end{array}$ & $\begin{array}{l}3.80 \\
(1.14)^{* *}\end{array}$ & $\begin{array}{c}3.66 \\
(1.33)^{* *}\end{array}$ & $\begin{array}{c}3.21 \\
(1.26)^{* *}\end{array}$ & $\begin{array}{c}3.76 \\
(1.20)^{* * *}\end{array}$ & $\begin{array}{c}3.22 \\
(1.36)^{* * *}\end{array}$ \\
\hline Counterargue_8 & $\begin{array}{c}3.50 \\
(1.42)^{*}\end{array}$ & $\begin{array}{c}3.75 \\
(1.29)^{*}\end{array}$ & $\begin{array}{c}3.93 \\
(1.26)^{*}\end{array}$ & $\begin{array}{c}3.76 \\
(1.28)\end{array}$ & $\begin{array}{c}3.67 \\
(1.41)\end{array}$ & $\begin{array}{c}4.03 \\
(1.24)^{* * *}\end{array}$ & $\begin{array}{c}3.74 \\
(1.36)^{* * *}\end{array}$ \\
\hline Absorption & $\begin{array}{c}3.31 \\
(0.89)^{* * *}\end{array}$ & $\begin{array}{c}2.99 \\
(1.03)^{* * *}\end{array}$ & $\begin{array}{c}3.63 \\
(0.82)^{* * *}\end{array}$ & $\begin{array}{c}3,13 \\
(0.97)^{* *}\end{array}$ & $\begin{array}{c}3,46 \\
(0.92)^{* *}\end{array}$ & $\begin{array}{c}3.17 \\
(0.85)^{*}\end{array}$ & $\begin{array}{c}3.41 \\
(1.02)^{*}\end{array}$ \\
\hline $\begin{array}{l}\text { Empathetic } \\
\text { Emotionality }\end{array}$ & $\begin{array}{c}3.91 \\
(1.03)^{* * *}\end{array}$ & $\begin{array}{c}3.66 \\
(1.10)^{* * *}\end{array}$ & $\begin{array}{c}4.20 \\
\left(0.79^{* * *}\right.\end{array}$ & $\begin{array}{c}3.70 \\
(1.04)^{* * *}\end{array}$ & $\begin{array}{c}4.09 \\
(0.94)^{* * *}\end{array}$ & $\begin{array}{c}3.72 \\
(1.03)^{* *}\end{array}$ & $\begin{array}{c}4.07 \\
(0.96)^{* *}\end{array}$ \\
\hline $\begin{array}{l}\text { Source } \\
\text { Believability }\end{array}$ & $\begin{array}{c}3.62 \\
(0.95)^{* * *}\end{array}$ & $\begin{array}{c}3.34 \\
(1.06)^{* * *}\end{array}$ & $\begin{array}{c}3.95 \\
(0.81)^{* * *}\end{array}$ & $\begin{array}{c}3.52 \\
(0.97)^{*}\end{array}$ & $\begin{array}{c}3.72 \\
(0.97)^{*}\end{array}$ & $\begin{array}{c}3.47 \\
(0.95)^{* *}\end{array}$ & $\begin{array}{c}3.76 \\
(0.98)^{* *}\end{array}$ \\
\hline Expectedness & $\begin{array}{c}3.49 \\
(1.20)^{* * *}\end{array}$ & $\begin{array}{c}1.58 \\
(0.77)^{* * *}\end{array}$ & $\begin{array}{c}2.54 \\
(0.86)^{* * *}\end{array}$ & $\begin{array}{l}2.48 \\
(1.21)\end{array}$ & $\begin{array}{c}2.53 \\
(1.26)\end{array}$ & $\begin{array}{c}2.53 \\
(1.25)\end{array}$ & $\begin{array}{c}2.48 \\
(1.23)\end{array}$ \\
\hline $\begin{array}{l}\text { Perceived } \\
\text { Persuasive }\end{array}$ & $\begin{array}{c}3.27 \\
(0.81)^{* * *}\end{array}$ & $\begin{array}{c}3.73 \\
(0.83)^{* * *}\end{array}$ & $\begin{array}{c}3.84 \\
(0.72)^{* * *}\end{array}$ & $\begin{array}{c}3.52 \\
(0.84)^{*}\end{array}$ & $\begin{array}{c}3.69 \\
(0.81)^{*}\end{array}$ & $\begin{array}{c}3.50 \\
(0.78)^{*}\end{array}$ & $\begin{array}{c}3.71 \\
(0.85)^{*}\end{array}$ \\
\hline Counterargue & $\begin{array}{c}2.12 \\
(1.16)^{* * *}\end{array}$ & $\begin{array}{c}2.91 \\
(0.92)^{* * *}\end{array}$ & $\begin{array}{c}3.04 \\
(1.16)^{* * *}\end{array}$ & $\begin{array}{c}2.81 \\
(1.06)^{*}\end{array}$ & $\begin{array}{c}2.51 \\
(1.21)^{*}\end{array}$ & $\begin{array}{c}2.84 \\
(1.12)^{*}\end{array}$ & $\begin{array}{c}2.54 \\
(1.17)^{*}\end{array}$ \\
\hline $\begin{array}{l}\text { Behavioral } \\
\text { Intention }\end{array}$ & $\begin{array}{c}3.35 \\
(1.32)\end{array}$ & $\begin{array}{c}3.22 \\
(1.24)\end{array}$ & $\begin{array}{l}3.46 \\
(1.12)\end{array}$ & $\begin{array}{c}3.39 \\
(1.19)\end{array}$ & $\begin{array}{c}3.31 \\
(1.26)\end{array}$ & $\begin{array}{c}2.68 \\
(1.13)^{* * *}\end{array}$ & $\begin{array}{c}3.88 \\
(1.04)^{* * *}\end{array}$ \\
\hline
\end{tabular}

${ }^{*} \mathrm{p}<.05, * * \mathrm{p}<.01, * * * \mathrm{p}<.001$ 


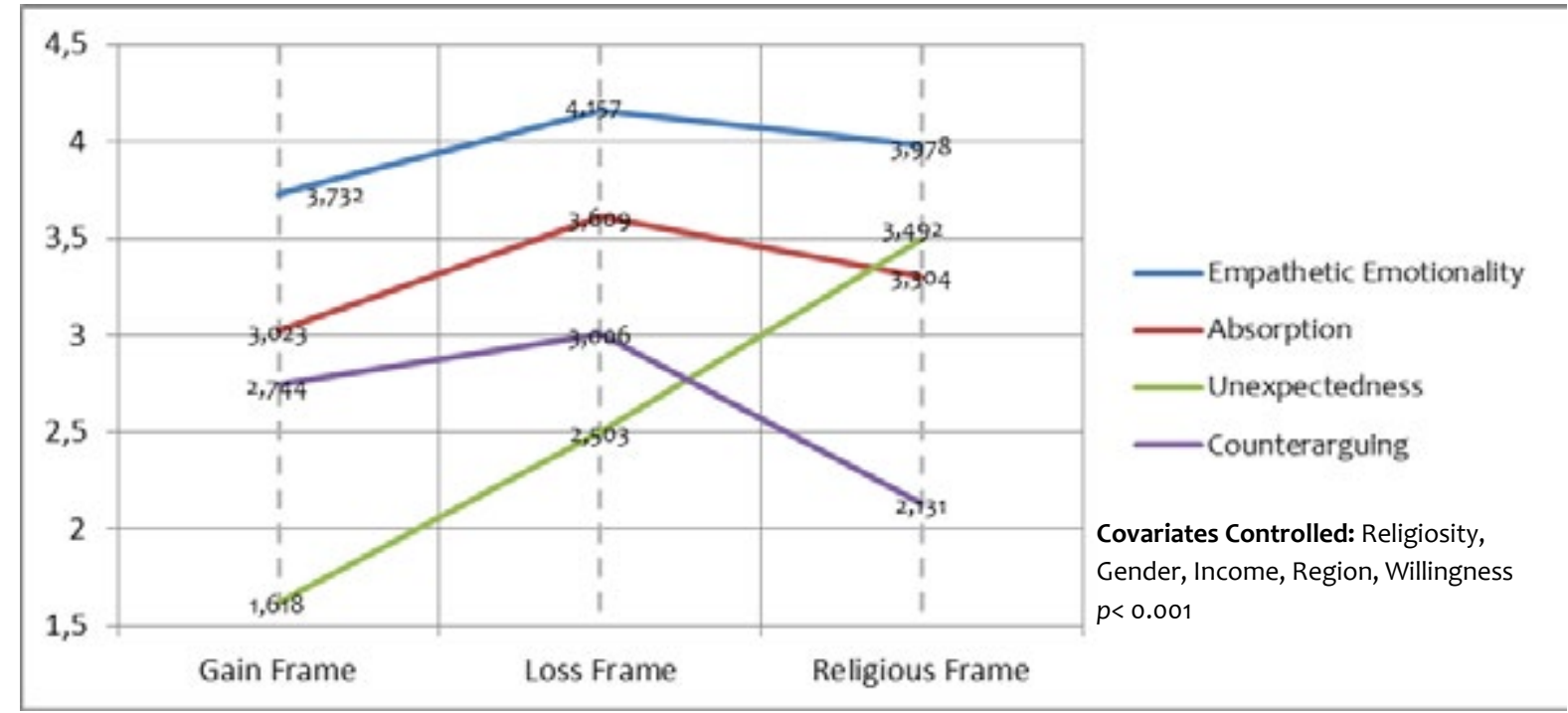

Figure 1. Estimated Marginal Means for Framing Conditions

The results of ANCOVA models predicting independent variables were presented in Table 4 . The covariance model for the exposure to framing conditions indicated significant results in influencing the empathic emotionality $(F(1,378)=5.23, p<.05)$, absorption $(F(1,378)=8.68, p=.01)$, believability $(F(1,378)$ $=5.53, p<.05)$, unexpectedness $(F(1,378)=238.225, p<.001)$, perceived persuasiveness $(F(1,378)=23.531$, $p<.001)$, counterarguing $(F(1,378)=32.026, p<.001)$. However, there found a single insignificant impact for the framing condition on behavioral intentions to get vaccinated $(F(1,258)=0.48, p=.826)$. The mean scores of all framed conditions describing the necessity of getting inoculated unveiled that young individuals presented more favorable attitudes toward getting vaccinated in the religious framed condition $(M=3.36$, $\mathrm{SE}=0.12)$ in comparison to the gain framing condition $(\mathrm{M}=3.21, \mathrm{SE}=0.11)$.

Table 5. Covariates Predicting Dependent Variables

\begin{tabular}{llllllll}
\hline \multicolumn{7}{c}{ Dependent Variables } \\
(F coefficients)
\end{tabular}

$* \mathrm{p}<.05, * * \mathrm{p}<.01, * * * \mathrm{p}<.001$ 
The following model estimated that individual religiosity level has several impacts toward dependent variables. According to test of between-subjects effects, the religiosity was significantly correlated to empathetic emotionality $(F(1,258)=29.90, p<.001)$, absorption $(F(1,258)=22.71, p<.001)$, believability $(F$ $(1,258)=10.16, p<.005)$, perceived persuasiveness $(F(1,258)=6.36, p<.05)$, and counterarguing $(F(1,258)$ $=6.75, p<.05)$ but not with unexpectedness of the message $(F(1,258)=.91, p=.343)$ and behavioral intent $(F(1,258)=.73, p=.395)$. While the sense of message unexpectedness $(M=2.53$, $S E=0.09)$ was higher in individuals who were reported to be religious, the mean scores of vaccination intentions $(M=3.39, \mathrm{SE}=$ 0.93 ) were calculated higher in non-religious individuals. Results also showed that there were significant interactions between religiosity and the framing conditions ( $p<.001)$.

According to the ANCOVA results, the willingness to vaccination intake has insignificant associations with unexpectedness perception $(F(1,258)=0.03, p=.855)$ and counterarguing proneness $(F(1,258)=2.273$, $p=.132)$. There were also significant associations for empathetic emotionality $(F(1,370)=10.635, p<.001)$, message absorption $(F(1,370)=6.389, p<.05)$, believability $(F(1,370)=5.764, p<.05)$ and behavioral intention $(F(1,370)=64.396, p<.001)$. The mean scores of the willingness for getting vaccination demonstrated that participants who have eagerness to inoculation mostly responded favorably to ad messages. There were also significant interactions between framing conditions and willingness construct. This interaction effect significantly predicted the absorption $(F(1,378)=3.512, p<.05)$ and counterarguing $(F(1,378)=5.255, p$ $<.05)$. Particularly highlighted by the participants who were enthusiastic about vaccination behavior were absorption $(M=3.41, S E=.07)$ and empathetic emotionality $(M=4.06, S E=.06)$.

\section{Discussion}

This paper empirically investigated the influence of religious message framing on attitudes to vaccination programs by comparing it with usual framing styles such as loss/gain framing. Hypotheses were tested by using a set of individual message framing stimuli. The content of the messages included the actual statements by the state authorities, and people were very familiar with those declarations. Thus, the possibility of acquiring the common responses of participants was encouraged in pandemic conditions. Through an experimental procedure, the current study explored that religious framed messages, in a brochure, significantly reduce counterarguing against vaccination campaigns. When individuals were exposed to a vaccination message including sacred context, they might have a higher tendency to avoid critical thinking for the message information, and the framing impact is likely perceived as more believable. This is primarily due to an influence associated with individuals' intense emotional responses and absorption into the message content. The findings demonstrate that religious framed communications strengthen individuals' perception of unexpectedness for the message and empower them to build strong connections with the message characters which impress vaccination-related arguments. Furthermore, a religious framing abates the sense of being persuaded by the message and enhances the attitudinal orientation. Thus, individuals might have favorable feelings towards the vaccination behavior by avoiding a negative response that arises from the degree of perceived persuasiveness. Individuals reported higher levels of favorable emotions after viewing the religious-framed message, which possibly reduced the counterarguing propensity against the vaccination program. The results revealed significant main effects of framing conditions on message absorption, unexpectedness, reducing persuasiveness perception, and counterarguing. In addition, a significant interaction effect between framing and religiosity was found on dependent variables which were categorized through an Extended-ELM point of view.

\section{Theoretical Implications}

The current paper contributes theoretical implications to the general literature of both pandemic and communication studies. Prior studies emphasized mainly the influence of either loss-framed or gain-framed messages created to build favorable attitudes to desired health behaviors (Borah et al., 2021; O'Keefe and Jensen, 2007; Robbins and Niederdeppe, 2019; Rothman et al., 1999; Yu et al., 2010). For instance, individuals exposed to messages containing potential benefits reported a higher degree of prevention intentions to Fetal Alcohol Spectrum Disorder which refers to the superiority of gain framing compared to loss-framed communications (Yu et al., 2010) and gain-framed messages in narrative format was more effective in inducing favorable feelings whereas loss-framed narrative stirred up stronger negative sensations (Liu and Yang, 2020). Various types of framing impacts such as temporal framing were examined (Shen and Kim, 2020; Kim and Nan, 2019), and the empirical studies found that a proximal frame with a moderate level of fear has led to a more positive attitude toward Eco-Friendly Clothing advertising compared to distanceframing (Shen and Kim, 2020). Also, recent studies examined the influence of message framing initiatives on inoculation and vaccination resistance (Palm et al., 2021; Peng et al., 2021). These studies supported the 
idea that framing might have an impact on attitudes and behavioral intentions to involve in the vaccination program. However, the preceding literature has not yielded any consideration into the direct comparison of religious-framed communications with frequently used frames. On that account, the present article focuses empirically on the influence of religious context on attitudes and, to the best of our knowledge, makes an updated contribution to this gap in the literature.

In addition to that, the present article provides evidence to the information processing literature through addressing the religious framing in the context of Extended-ELM. The requirement of appealing communication attempts has been frequently discussed to improve both compliance with preventive measures and attitudes toward vaccination during the pandemic period. Based on this argument, the present article has revealed that the message frame focusing on religious context could lead individuals to make a more positive evaluation than the usual message contexts that trigger emotions such as fear and hope. The Extended-ELM model emphasizes message absorption and the creation of attitudes through enhancing a sense of similarity towards the characters (Moyer-Gusé and Nabi, 2010; Slater and Rouner, 2002), while the classical ELM model deals with the cognitive processing of strong and weak arguments (Haugtvedt, Petty, and Cacioppo, 1992; Petty, Cacioppo, and Schumann, 1983). The message involvement and strong empathetic responses required to overcome counterarguing and, thus to achieve the desired outcomes were conceptualized as Extended-ELM in health communications (Moyer-Gusé and Nabi, 2010). ExtendedELM argues that this result might be primarily possible by narrating the message in a form of a story. It seems that religious framing, which refers to a visual story about the rightful due violation of others in the vaccination issue, definitely traces the paths presented by the Extended-ELM. Although religious framing has not been argued directly in the context of the Extended-ELM so far, the current study claimed that religion stimulates the state of being drawn into the message and emotional responses as well. Further, evidence was found in terms of reducing counterarguments that were associated with message absorption. As a critical contribution to the relevant literature, the unexpectedness of the message was strongly associated with depletion of counter-arguments than message absorption. However, considering the powerful links between absorption and unexpectedness, it should be noticed that both have an overriding interaction in preventing the generation of opposing ideas.

Incorporating the unexpectedness dimension enhanced the descriptive ability of the E-ELM model in reducing counterarguing toward vaccination attitudes. As anticipated, participants with a higher sense of unexpectedness indicated powerful transformation in counterarguing following the immersion into the religious message. Absorption into the message content and empathic emotionality also seem to significantly eliminate counterarguments through lowering the persuasiveness perception of the message. To reach an overall evaluation, in the religious framing condition, it is possible to assert that the strong links between predictors have presented novel moderator and mediator variables to the Extended-ELM context. Besides, the traditional information processing model emphasizes the principle that strong and weak arguments could be processed through either central or peripheral routes. Besides, the traditional information processing model emphasizes the principle that strong and weak arguments could be processed through either central or peripheral routes. Through the Extended-ELM perspective, it has been confirmed that religious framing could act as an incentive in activating the emotional intensity rather than the strong and weak features stimulating the critical evaluation. It can be assumed that religiosity creates an attitude via empathic processing due to avoiding the tendency of argument-based thinking, and blurring the distinction between peripheral and central routes. The religious-framed stimulus with the theme of rightful due instilled an idea in young minds that unvaccinated individuals would violate the rightful due of others, instead of the physical utilities of the vaccine on health and the pandemic. This context indirectly linked the vaccine with an emotional benefit. As a result, both unexpectedness of the message was perceived and individuals with religious responsiveness were prevented from generating critical thoughts.

\section{Managerial Implications}

This research provides an advantageous messaging strategy, as the results ensure influential inferences for communication specialists to promote desired health behaviors, particularly to build favorable attitudes toward vaccination. The findings suggest that using religious framing context in vaccine communication leads to a robust influence on several issues than the loss-or-gain framing. This means that health communicators need to concentrate on designing a religious perspective in the heart of the messages, given the fact that individuals experience a religiously-based decision-making process during times of crisis. Health communicators could extend several implications for the target audiences to 
encourage deep emotional responses through effective message designs in a religious focus. Stimulating individuals to engage the vaccination program over religious framing will likely escalate the sense of an unanticipated impact and reduce counter-responses, thus leading an emotional information-processing. This way of building strong attitudes through emotional intensity could provide powerful health communications results. Because religious individuals find notable of violating others' rightful due as a divine prohibition, use of alike sacred context in the message might lead them to appraise the information more significantly, thus to involve in the vaccination program. As an important determinant in which individuals refuge in difficult times (Bentzen, 2020; Boguszewski et al., 2020; Waqas, 2021), religious-framed communication could offer great opportunities for individuals to engage in vaccination and other health behaviors.

\section{Limitations and Suggestions for Future Research}

The findings of the study should be evaluated considering several limitations. First, advancing on a young sample was the result of focusing on the target group which was continuously debated during the pandemic period. Additionally, according to the data released, the vaccination rates among young individuals were generally at lower levels. However, testing the effect of religious context on a younger group may seem doubtful. The possibility that religious faith might have acquired a much more concrete meaning among the older ages was ignored within this respondents group. Secondly, even though the stimulus materials were designed as a pamphlet using the actual information from the state agencies to simulate a more realistic viewing of the message, the fact that the subjects were exposed to the framings in an experimental setting might have restricted the results to be generalized. In addition, the results prevailed in this study are based on the subjects' responses after a rapid exposure to message stimuli. The fourth limitation is sampling convenience. Although not included in the results of the study, the overwhelming majority of young individuals in the sample group certainly declared that they had been vaccinated at least one dose. The vaccination uptake rates and the characteristics of the sample group might have hindered the capability to explore the actual responses towards the framing stimuli. A more convenient sample, including unvaccinated individuals, would have provided more realistic findings to generalize the results. Future studies should explore how individuals including different age groups, different educational backgrounds, and cultures, if possible, react to various types of health communications in different framing perspectives. Thus, it will be possible to draw the representative quality of the study findings to a more realistic line. In addition, it has been found that the counterarguing inclination regarding the vaccination program could be overcome to some extent by the semantic value attributed to the message. To fight against vaccination indecisiveness, future studies should focus on how the message features could reach the emotional meaning in terms of shaping the vaccination-related beliefs and favorable attitudes to behavioral intentions.

\section{References}

Akhtar, N., Akhtar, M. N., Usman, M., Ali, M., and Siddiqi, U. I. (2020). COVID-19 restrictions and consumers' psychological reactance toward offline shopping freedom restoration. The Service Industries Journal, 40(13), 891-913.

Banker, S., and Park, J. (2020). Evaluating prosocial COVID-19 messaging frames: Evidence from a field study on Facebook. Judgment and Decision Making, 15(6), 1037-1043.

Ben-Ze'ev, A. (2000). The subtlety of the emotions. (First Edit). The MIT Press.

Bentzen, J. S. (2020). In crisis, we pray: Religiosity and the COVID-19 pandemic. https://www.researchgate.net/ profile/Jeanet-Bentzen/publication/343627578_In_Crisis_We_Pray_Religiosity_and_the_COVID-19_ Pandemic/links/5f34e703458515b7291bf329/In-Crisis-We-Pray-Religiosity-and-the-COVID-19-Pandemic. pdf

Bigman, C. A., Cappella, J. N., and Hornik, R. C. (2010). Effective or ineffective: Attribute framing and the human papillomavirus (HPV) vaccine. Patient Education and Counseling, 81, S70-S76.

Bin Shen, and Kim, Y. (2020). Green with Fear: fear Appeals and temporal framing in eco-friendly clothing advertising. Clothing and Textiles Research Journal, November, 1-15. https://doi. org/10.1177/0887302X20968821

Boguszewski, R., Makowska, M., Bożewicz, M., and Podkowińska, M. (2020). The COVID-19 pandemic's impact on religiosity in Poland. Religions, 11(12), 646-660.

Borah, P., Hwang, J., and Hsu, Y. C. (Louise). (2021). COVID-19 vaccination attitudes and intention: Message framing and the moderating role of perceived vaccine benefits. Journal of Health Communication, 1-11. https://doi.org/10.1080/10810730.2021.1966687. 
Boyer, P., and Ramble, C. (2001). Cognitive templates for religious concepts: cross-cultural evidence for recall of counter-intuitive representations. Cognitive Science, 25, 535-564.

Bozkurt, H. B. (2018). An overview of vaccine rejection and review of literature. Kafkas Journal of Medical Sciences, 8(1), 71-76. https://doi.org/10.5505/kjms.2018.12754

Briñol, P., and Petty, R. E. (2009). Source factors in persuasion: A self-validation approach,. European Review of Social Psychology, 20(1), 49-96.

Cacioppo, J. T., and Petty, R. E. (1984). The elaboration likelihood model of persuasion. Advances in Consumer Research, 11, 673-675.

Callaghan, T., Moghtaderi, A., Lueck, J. A., Hotez, P., Strych, U., Dor, A., Fowler, E. F., and Motta, M. (2021). Correlates and disparities of intention to vaccinate against COVID-19. Social Science and Medicine, 272(January), 1-5. https://doi.org/10.1016/j.socscimed.2020.113638.

Ceylan, M., and Hayran, C. (2021). Message framing effects on individuals' social distancing and helping behavior during the COVID-19 pandemic. Frontiers in Psychology, 12(March), 1-14. https://doi.org/10.3389/ fpsyg.2021.579164.

Cherry, K. E., Sampson, L., Nezat, P. F., Cacamo, A., Marks, L. D., and Galea, S. (2015). Long-term psychological outcomes in older adults after disaster: relationships to religiosity and social support. Aging \& Mental Health, 19(5), 430-443.

Cho, H., and Salmon, C. T. (2007a). Unintended effects of health communication campaigns. Journal of Communication, 57(2), 293-317. https://doi.org/10.1111/j.1460-2466.2007.00344.x.

Cho, H., and Salmon, C. T. (2007b). Unintended Effects of Health Communication Campaigns. Journal of Communication, 57, 293-317.

Chong, D., and Druckman, J. N. (2007). Framing theory. Annual Review of Political Science, 10, 103-126. https:// doi.org/10.1146/annurev.polisci.10.072805.103054

Cohen, J. (2001). Defining identification: A theoretical look at the identification of audiences with media characters. Mass Communication \& Society, 4, 245-264.

Cotte, J., Coulter, R. A., and Moore, M. (2005). Enhancing or disrupting guilt: The role of ad credibility and perceived manipulative intent. Journal of Business Research, 58(3), 361-368. https://doi.org/10.1016/ S0148-2963(03)00102-4.

Cranney, S. (2017). Why did god make me this way? Religious coping and framing in the virtuous pedophile community. Journal for the Scientific Study of Religion, 56(4), 852-868.

Cummings, S. M., Neff, J. A., and Husaini, B. A. (2003). Functional impairment as a predictor of depressive symptomatology: The role of race, religiosity, and social support. Health \& Social Work, 28(1), 23-32.

De Graaf, A., Hoeken, H., Sanders, J., and Beentjes, H. (2009). The role of dimensions of narrative engagement in narrative persuasion. Communications, 34, 385-405. https://doi.org/10.1515/CoMM.2009.024.

Deslatte, A. (2020). To shop or shelter? Issue framing effects and social-distancing preferences in the COVID-19 pandemic. Journal of Behavioral Public Administration, 3(1), 1-13. https://doi.org/10.30636/jbpa.31.158.

Dillard, J. P., and Shen, L. (2005). On the nature of reactance and its role in persuasive health communication. Communication Monographs, 72(2), 144-168. https://doi.org/10.1080/03637750500111815

Dotson, M. J., and Hyatt, E. M. (2000). Religious symbols as peripheral cues in advertising: A replication of the elaboration likelihood model. Journal of Business Research, 48(1), 63-68. https://doi.org/10.1016/S01482963(98)00076-9

Emmons, R. A. (2005). Emotion and religion. In Raymond F. Paloutzian \& C. L. Park (Eds.), Handbook of the psychology of religion and spirituality (pp. 235-252). The Guilford Press.

Epstein, R. N. E. (2018). Implications for community health practitioners: Framing religion and spirituality within a social ecological framework. In D. Oman (Ed.), Why Religion and Spirituality Matter for Public Health, Religion, Spirituality and Health: A Social Scientific Approach (pp. 305-322). Springer. https://doi. org/10.1007/978-3-319-73966-3_17 
Etikan, I., Musa, S. A., and Alkassim, R. S. (2016). Comparison of convenience sampling and purposive sampling. American Journal of Theoretical and Applied Statistics, 5(1), 1-4. https://doi.org/10.11648/j. ajtas.20160501.11

Exline, J. J., Smyth, J. M., Gregory, J., Hockemeyer, J., and Tulloch, H. (2005). Religious framing by individuals with PTSD when writing about traumatic experiences. The International Journal for the Psychology of Religion, 15(1), 17-33. https://doi.org/10.1207/s15327582ijpr1501

Gallagher, K. M., and Updegraff, J. A. (2012). Health message framing effects on attitudes, intentions, and behavior: a meta-analytic review. Annals of Behavioral Medicine, 43(1), 101-116.

George, L. K., Larson, D. B., Koenig, H. G., and McCullough, M. E. (2000). Spirituality and health: What we know, what we need to know. Journal of Social and Clinical Psychology, 19(1), 102-116.

Gerend, M. A., and Sias, T. (2009). Message framing and color priming: How subtle threat cues affect persuasion. Journal of Experimental Social Psychology, 45(4), 999-1002.

Giordano, A. L., Prosek, E. A., and Lankford, C. T. (2014). Predicting empathy: The role of religion and spirituality. Journal of Professional Counseling: Practice, Theory \& Research, 41(2), 53-66. https://doi.org /10.1080/15566382.2014.12033938

Gollust, S. E., and Cappella, J. N. (2014). Understanding public resistance to messages about health disparities. Journal of Health Communication, 19(4), 493-510. https://doi.org/10.1080/10810730.2013.821561

Green, M. C. (2006). Narratives and cancer communication. Journal of Communication, 56, 163-183. https:// doi.org/10.1111/j.1460-2466.2006.00288.x

Green, M. C., and Brock, T. C. (2000). The role of transportation in the persuasiveness of public narratives. Journal of Personality and Social Psychology, 79(5), 701-721.

Haugtvedt, C. P., Petty, R. E., and Cacioppo, J. T. (1992). Need for cognition and advertising: Understanding the role of personality variables in consumer behavior. Journal of Consumer Psychology, 1(3), 239-260.

Hobson-West, P. (2003). Understanding vaccination resistance: Moving beyond risk. Health, Risk and Society, 5(3), 273-283. https://doi.org/10.1080/13698570310001606978

Huber, S., and Huber, O. W. (2012). The centrality of religiosity scale (CRS). Religions, 3(3), 710-724. https:// doi.org/10.3390/rel3030710

Hughes, J. W., Tomlinson, A., Blumenthal, J. A., Davidson, J., Sketch Jr, M. H., and Watkins, L. L. (2004). Social support and religiosity as coping strategies for anxiety in hospitalized cardiac patients. Annals of Behavioral Medicine, 28(3), 179-185.

IPSOS. (2021). Korona virüs salgını ve toplum. https://www.ipsos.com/tr-tr/asi-olmamis-bireylerin-65i-asi-sirasigeldiginde-olma-niyetinde

Kim, H. K., Lee, T. K., and Kong, W. Y. (2020). The interplay between framing and regulatory focus in processing narratives about HPV vaccination in Singapore. Health Communication, 35(2), 222-232.

Kim, J., and Nan, X. (2019). Temporal framing effects differ for narrative versus non-narrative messages: The case of promoting HPV vaccination. Communication Research, 46(3), 401-417. https://doi. org/10.1177/0093650215626980

Kim, K., Bonn, M., and Cho, M.(2021). Clean safety message framing as survival strategies for small independent restaurants during the COVID-19 pandemic. Journal of Hospitality and Tourism Management, 46, 423-431.

Krakow, M. M., Yale, R. N., Jensen, J. D., Carcioppolo, N., and Ratcliff, C. L. (2018). Comparing mediational pathways for narrative- and argument-based messages: Believability, counterarguing, and emotional reaction. Human Communication Research, 44(3), 299-321. https://doi.org/10.1093/hcr/hqyoo2

Kreuter, M. W., Green, M. C., Cappella, J. N., Slater, M. D., Wise, M. E., Storey, D., Clark, E. M., O’Keefe, D. J., Erwin, D. O., Holmes, K., Hinyard, L. J., Houston, T., and Woolley, S. (2007). Narrative communication in cancer prevention and control: A framework to guide research and application. Annals of Behavioral Medicine, 33(3), 221-235. https://doi.org/10.1007/BF02879904

Landrum, A. R., Olshansky, A., and Richards, O. (2021). Differential susceptibility to misleading flat earth arguments on youtube. Media Psychology, 24(1), 136-165. https://doi.org/10.1080/15213269.2019.16694 61 
Lane, V., and Jacobson, R. (1997). The reciprocal impact of brand leveraging: Feedback effects from brand extension evaluation to brand evalution. Marketing Letters, 8(3), 261-271.

Lee, A. Y., and Aaker, J. L. (2004). Bringing the frame into focus: the influence of regulatory fit on processing fluency and persuasion. Journal of Personality and Social Psychology, 86(2), 205-218.

Lim, J. R., Liu, B. F., Egnoto, M., and Roberts, H. A. (2019). Individuals' religiosity and emotional coping in response to disasters. Journal of Contingencies and Crisis Management, 27(4), 331-345. https://doi. org/10.1111/1468-5973.12263

Liu, S., and Yang, J. Z. (2020). Incorporating message framing into narrative persuasion to curb e-cigarette use among college students. Risk Analysis, 40(8), 1677-169o. https://doi.org/10.1111/risa.13502

Lumpkins, C. Y. (2010). Sacred symbols as a peripheral cue in health advertisements: An assessment of using religion to appeal to African American women about breast cancer screening. Journal of Media and Religion, 9(4), 181-201. https://doi.org/10.1080/15348423.2010.521083

Markstrom, C. A., Huey, E., Stiles, B. M., and Krause, A. L. (2010). Frameworks of caring and helping in adolescence: Are empathy, religiosity, and spirituality related constructs? Youth \& Society, 42(1), 59-80. https://doi.org/10/1177/ 0044118X09333644

Milligan, M. A., Hoyt, D. L., Gold, A. K., Hiserodt, M., and Otto, M. W. (2021). COVID-19 vaccine acceptance: influential roles of political party and religiosity. Psychology, Health and Medicine, oo(00), 1-11. https:// doi.org/10.1080/13548506.2021.1969026

Moyer-Gusé, E. (2008). Toward a theory of entertainment persuasion: Explaining the persuasive effects of entertainment-education messages. Communication Theory, 18(3), 407-425. https://doi.org/10.1111/ j.1468-2885.2008.00328.x

Moyer-Gusé, E., and Nabi, R. L. (2010). Explaining the effects of narrative in an entertainment television program: Overcoming resistance to persuasion. Human Communication Research, 36(1), 26-52. https:// doi.org/10.1111/j.1468-2958.2009.01367.x

Murat, E., Karabulut, Ö., Benlioğlu, B., Öztürk, M. ve Maşe, I. (2021). Aşı karşıtlarından Maltepe'de miting. DHA. https://www.dha.com.tr/istanbul/asi-karsitlarindan-maltepede-miting/haber-1847950

Nabi, R. L., Moyer-Gusé, E., and Byrne, S. (2007). All joking aside: A serious investigation into the persuasive effect of funny social issue messages. Communication Monographs, 74(1), 29-54. https:/doi. org/10.1080/03637750701196896

Naseri, A., and Tamam, E. (2012). Impact of Islamic religious symbol in producing favorable attitude toward advertisement. Revista de Administratie Publica Si Politici Sociale, 8, 61-77.

Niederdeppe, J., Kim, H. K., Lundell, H., Fazili, F., and Frazier, B. (2012). Beyond counterarguing: Simple elaboration, complex integration, and counterelaboration in response to variations in narrative focus and sidedness. Journal of Communication, 62(5), 758-777. https://doi.org/10.1111/j.1460-2466.2012.01671.x

O'Keefe, D. J., and Jensen, J. D. (2007). The relative persuasiveness of gain-framed loss-framed messages for encouraging disease prevention behaviors: A meta-analytic review. Journal of Health Communication, 12(7), 623-644.

Olagoke, A. A., Olagoke, O. O., and Hughes, A. M. (2021). Intention to vaccinate against the novel 2019 coronavirus disease: The role of health locus of control and religiosity. Journal of Religion and Health, 60(1), 65-80. https://doi.org/10.1007/s10943-020-01090-9

Ozorak, E. W. (2005). Cognitive approaches to religion. In R. F. Paloutzian and C. L. Park. (Eds.), Handbook of the psychology of religion and spirituality (pp. 216-234). The Guilford Press.

Palm, R., Bolsen, T., and Kingsland, J. T. (2021). The effect of frames on COVID-19 vaccine resistance. Frontiers in Political Science, 3, 41.

Peng, L., Guo, Y., and Hu, D. (2021). Information framing effect on public's intention to receive the COVID-19 vaccination in China. Vaccines, 9, 1-17.

Petty, R. E., Cacioppo, J.T., and Schumann, D. (1983). Central and peripheral routes to advertising effectiveness: The moderating role of involvement. Journal of Consumer Research, 10(2), 135-146. 
Petty, Richard E., and Cacioppo, J. T. (1986). Elaboration likelihood model. Advances in Experimental Social Psychology, 19, 124-205. https://doi.org/DOI: 10.1016/S0065-2601(08)60214-2

Ragsdale, J. . D., and Durham, K. R. . (1986). Audience response to religious fear appeals. Review of Religious Research, 28(1), 40-50.

Randolph, W., and Viswanath, K. (2004). Lessons learned from public health mass media campaigns: marketing health in a crowded media world. Annual Review of Public Health, 25, 419-437.

Reynolds-Tylus, T. (2019). Psychological reactance and persuasive health communication: A review of the literature. Frontiers in Communication, 4, 1-12.

Robbins, R., and Niederdeppe, J. (2019). Testing the role of narrative and gain-loss framing in messages to promote sleep hygiene among high school students. Journal of Health Communication, 24(1), 84-93.

Rothman, A. J., Martino, S. C., Bedell, B. T., Detweiler, J. B., and Salovey, P. (1999). The systematic influence of gain-and loss-framed messages on interest in and use of different types of health behavior. Personality and Social Psychology Bulletin, 25(11), 1355-1369.

Rothman, A. J., and Salovey, P. (1997). Shaping perceptions to motivate healthy behavior: The role of message framing. Psychological Bulletin, 121, 3-19.

Rucker, D. D., and Petty, R. E. (2004). When resistance is futile: Consequences of failed counterarguing for attitude certainty. Journal of Personality and Social Psychology, 86(2), 219-235. https://doi. org/10.1037/0022-3514.86.2.219

Slater, M. D., and Rouner, D. (2002a). Entertainment-education and elaboration likelihood: Understanding the processing of narrative persuasion. Communication Theory, 12(2), 173-191.

Slater, M. D., and Rouner, D. (2002b). Entertainment-education and elaboration likelihood: Understanding the processing of narrative persuasion. Communication Theory, 12, 173-191.

Slater, Michael D., and Rouner, D. (2002). Entertainment-education and elaboration likelihood: Understanding the processing of narrative persuasion. Communication Theory, 12(2), 173-191. https:// doi.org/10.1111/j.1468-2885.2002.tboo265.x

Smith, S. M., and Petty, R. E. (1996). Message framing and persuasion: A message processing analysis. Personality and Social Psychology Bulletin, 22(3), 257-268.

Taylor, V. A., Halstead, D., and Haynes, P. J. (2010). Consumer responses to Christian religious symbols in advertising. Journal of Advertising, 39(2), 79-92. https://doi.org/10.2753/JOA0091-3367390206

Vraga, E. K., and Jacobsen, K. H. (2020). Strategies for effective health communication during the coronavirus pandemic and future emerging infectious disease events. World Medical \& Health Policy, 12(3), 233-241.

Walter, N., and Cohen, J. (2019). When less is more and more is less: The paradoxical metacognitive effects of counterarguing. Communication Monographs, 86(3), 377-397. https://doi.org/10.1080/03637751.2019 .1580378

Waqas, M. (2021). What drives Muslim Malaysian consumers' general attitude towards religious advertising? Journal of Islamic Accounting and Business Research, 12(1), 97-111. https://doi.org/10.1108/ JIABR-01-2020-0030

WHO. (2019). Ten threats to global health in 2019. https://www.who.int/news-room/spotlight/ten-threats-toglobal-health-in-2019

WHO. (2020). Pandemic fatigue - reinvigorating the public to prevent COVID-19. Policy framework for supporting pandemic prevention and management. https://doi.org/CC BY-NC-SA 3.0 IGO

Yale, R. N. (2013). Measuring narrative believability: Development and validation of the Narrative Believability Scale (NBS-12). Journal of Communication, 63(3), 578-599.

Yu, N., Ahern, L. A., Connolly-Ahern, C., and Shen, F. (2010). Communicating the risks of fetal alcohol spectrum disorder: Effects of message framing and exemplification. Health Communication, 25(8), 692-699. https://doi.org/10.1080/10410236.2010.521910 
Appendix 1. The Stimulus Materials

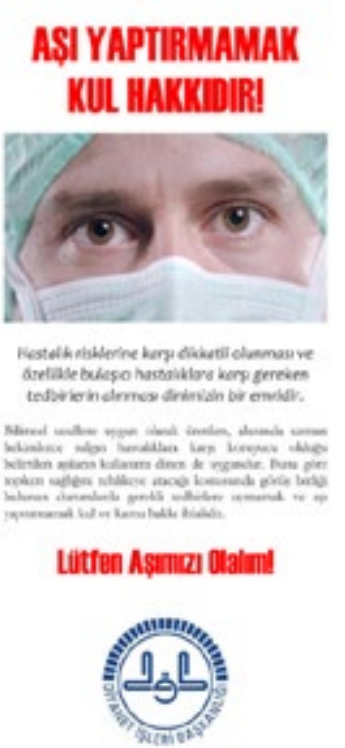

Religious Framing

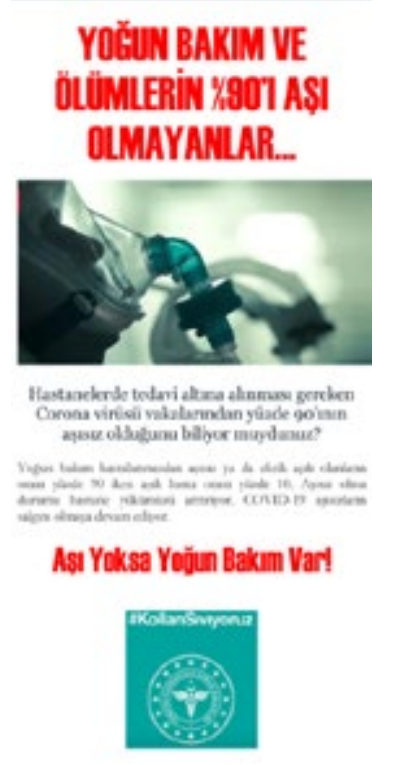

Loss Framing

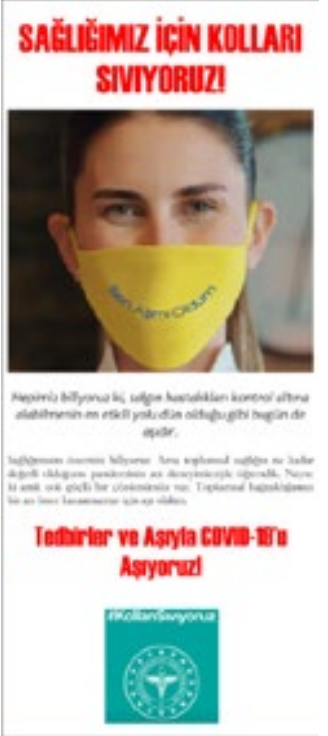

Gain Framing

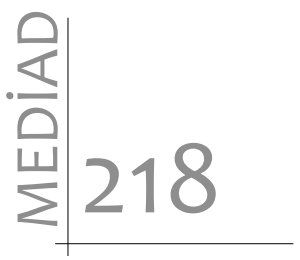




\title{
MEDIAD
}

\section{Așı Mesajlarına Yönelik Karşı Argüman Gelișiminde Dini Çerçeveleme Etkisinin Genişletilmiş-ELM Modeli Üzerinden İncelenmesi}

\author{
Mehmet Safa ÇAM
}

\section{Genișletilmiş Özet}

Sağlık davranışlarını teşvik eden mesajlar yaygın olarak kullanılmaktadır (Randolph ve Viswanath, 2004). Pandeminin dünya genelinde hızla yayılmasıyla birlikte, hastalık ve önleyici tedbirler hakkında bilgi miktarı daha da arttı (Vraga ve Jacobsen, 2020). ilk etapta koruyucu önlemlere uyumu artırmak amacıyla yayınlanmış olan farklı formatlardaki mesajlar (kamu spotları, yazı, makale, röportaj vb.), son dönemde aşıya yönelik olumlu tutumların geliştirilmesi amacıyla etkili iletişim stratejileri kapsamında tasarlanmaya devam etmektedir. Bununla birlikte, pandemik yorgunluk nedeniyle önlemlere uyma konusundaki isteksizliğe benzer şekilde (WHO, 2020), aşının kendisine ve aşı kampanyasına yönelik bir tereddütün varlığına şahit olunmaktadır (Palm vd., 2021). Sürü bağışıklığının etkinliği toplumun çoğunluğunun aşılanmasına bağlı olduğu için, kitlesel bir iletişim kampanyasıyla aşı programına yönelik olumlu tutumları biçimlendirmek büyük önem taşımaktadır.

Mesaja yönelik karşıt tepki gelişimi, sağlık iletişimi uygulamalarında karşılaşılan en önemli sorunlardan birisidir (Dillard ve Shen, 2005; Reynolds-Tylus, 2019). Bireyler özgürlüklerine yönelik bir tehdit algıladıklarında öfkelenmek, olumsuz düşünmek gibi psikolojik bir uyarılma hissetmekte ve ardından mesajın içeriğine yönelik olumsuz inançlar üretmektedirler (Gollust ve Cappella, 2014). Sağlık davranışlarını teşvik eden ikna edici mesajlar, seçim özgürlüğüne yönelik algılanan tehdit nedeniyle karşı argümanlara yol açmaktadır (Akhtar vd., 2020; Reynolds-Tylus, 2019). Sağılık davranışlarına yönelik olarak ortaya çıkan bu ön yargılar toplumsal bağışıkık ile ilişkilendirildiğinde, aşı konusunda tereddütlerin ortaya çıktığı ifade edilebilmektedir. Böylece, aşı aleyhine sergilenen inkar davranışları, aşının halk tarafından onaylanmasına dayanan kitlesel bağışıklamayı doğrudan tehdit eden bir endişe konusuna dönüşmektedir (Hobson-West, 2003).

Bireylerin aşı programına yönelik inanç ve tutumları, etkili iletişim stratejileri kapsamında hazırlanacak mesaj çerçeveleme teknikleriyle biçimlenebilmektedir. Covid-19 döneminde aşıya yönelik önleyici tedbirler ve tutumlar üzerinde mesaj çerçevelemenin etkinliğini inceleyen çok sayıda çalışma yapılmıştır (Banker ve Park, 2020; Borah vd., 2021; Ceylan ve Hayran, 2021). Pandemi odaklı çerçeveleme çalışmaları, temel olarak kayıp-kazanç yaklaşımları gibi ana akım tekniklerden türetilen formatlara odaklanmıştır (Deslatte, 2020; Kim vd., 2021). Farklı mesaj çerçeveleme yaklaşımlarının hem önleyici tedbirlere uyumu hem de aşıya yönelik olumlu tutumları nasıl geliştirdiğinin incelenmesi, etkili iletişim stratejilerinin geliștirilmesi açısından önemli görülmektedir. Bu çalışmanın konuyla ilgili literatüre katkısı, dini çerçevelemenin aşı tereddütü ve aşı programına yönelik karşıt tepkiler üzerindeki etkisini araştırmak olacaktır. Bu bağlamda, araştırma, Genişletilmiş-ELM modeli kapsamında mesajın duygusal olarak işlenmesi yoluyla dini çerçeveleme etkisinin bireyler üzerinde hangi sonuçlara yol açtığını ele almaktadır (Slater ve Rouner, 2002b). Bu doğrultuda, dini içeriğin aşılama tutumları üzerinde itici bir güç olduğu varsayılarak pandemi ve mesaj çerçeveleme literatürü alanındaki boşluğa katkıda bulunmak amaçlanmaktadır. Bilindiği kadarıyla daha önceki çalışmalar, Covid-19 döneminde aşı tereddütüne ilişkin dini çerçeveleme etkisine odaklanmamıştır. Dolayısıyla, bu makale, dini çerçevelemenin, iyi bilinen mesaj çerçeveleme yöntemleriyle karşılaştırıldığında, aşılama programına yönelik tutumların iyileştirilmesinde çeşitli faydalar sağlayabileceğini önermektedir. Bu sürecin bir parçası olarak, dini mesajların duygusal bir işleme sürecine dahil olup olmadığını daha iyi anlamak ve karşıt tepkiler üzerindeki çerçeveleme etkisini görmek amacıyla Genişletilmiş-ELM modelini de incelenmektedir.

Bu çalışmada, dini mesaj çerçevelemenin aşılama programına yönelik tutumlar üzerindeki etkisi ampirik olarak araştırılmıştır. Araştırma soruna, mesaj çerçeveleme uyaranları kullanılarak yanıtlar aranmıştır. Deneysel prosedür sonucunda elde edilen veriler, bir broşürdeki dini çerçeveli mesajın aşı kampanyasına yönelik karşıt tepkileri önemli ölçüde iyileştirdiğini doğrulamıştır. Bireyler kutsal bağlam içeren bir aşı mesajına maruz kaldıklarında, mesaj bilgisi için eleştirel düşünmekten kaçınma eğilimi nispeten ortaya çıkmış ve çerçeveleme etkisi daha ikna edici bir şekilde etkinliğini göstermiştir. Bu durum öncelikle, bireylerin yoğun duygusal tepkiler 
sergilemesi ve mesaj içeriğinin özümsenmesiyle ilişkili bir etkiden kaynaklanmıştır. Bulgular, dini çerçeveli iletişimin, bireylerin mesaja yönelik beklenmediklik algısını güçlendirdiğini ve aşı ile ilgili argümanları etkileyen mesaj karakterleriyle güçlü bağlantılar kurmalarını sağladığını göstermektedir. Ayrıca, dini çerçeveleme, mesajın algılanan ikna ediciliği üzerinde önemli bir rol oynamakta ve tutumsal yönelimi geliștirmektedir. Böylece bireyler, algılanan ikna niyetinden kaynaklanan olumsuzluktan kaçınarak aşı davranışına karşı olumlu inançlara sahip olabilmektedirler. Bireyler dini çerçeveli mesajla karşılaşmalarını takiben, daha anlamlı düzeylerde olumlu duygular bildirmiş, böylelikle, aşı programına yönelik muhtemel karşıt tepkilerin ortaya çıkmasının önüne geçilmiştir. Sonuçlar, çerçeveleme etkisinin mesaj ilginliği, beklenmediklik, ikna edicilik algısını azaltma ve karşıt tartışma üzerinde önemli bir rol oynadığını ortaya çıkarmıştır. Ayrıca GenişletilmişELM perspektifinden üretilen bağımlı değişkenler üzerinde çerçeveleme ve dindarlık etkileşiminden doğan önemli bir etki olduğu bulgulanmıştır.

Araştıranın sonuçları bazı kısıtlar eşliğinde değerlendirilmelidir. Aşılanmamış bireyleri dahil eden daha elverişli bir örneklemin sonuçları genellemek adına daha gerçekçi bulgular sağlayabileceği düşünülmektedir. Gelecekteki çalışmalar, mümkünse farklı yaş grupları, farklı eğitim durumları ve farklı kültürleri içeren bireylerin farklı çerçeveleme perspektiflerinde çeşitli sağlık iletişim türlerine nasıl tepki verdiğini araştırmalıdır. Böylece araştırma bulgularının temsil niteliğini daha gerçekçi bir çizgiye çekmek mümkün olacaktır. Ayrıca, aşılama programına ilişkin karşıt tepki eğiliminin, mesaja atfedilen anlamsal değerle bir ölçüde aşılabileceği tespit edilmiştir. Aşı kararsızlığına karşı mücadele etmek için, gelecekteki çalışmalar, aşı ile ilgili inançları ve davranışsal niyetlere yönelik olumlu tutumları şekillendirme açısından mesaj özelliklerinin duygusal anlama nasıl vurgu yapabileceğine odaklanmalıdır. Sonuçların hem ilgili literature hem de uygulayıcılara önemli çıkarımlar sunması beklenmektedir. 


\section{Çalışmanın Etik İzin Bilgileri}

Aksaray Üniversitesi İnsan Araştırmaları Etik Kurulu'nun 25/10/2021 tarihli 2021/07-29 protokol numaralı kararı çerçevesinde çalışma etik açıdan bir sakınca içermemektedir.

Etik değerlendirmeyi yapan kurul adı: Aksaray Üniversitesi İnsan Araştırmaları Etik Kurulu Etik değerlendirme kararı belge tarihi: 04/11/2021

Etik değerlendirme belgesi sayı numarası: E-34183927-000-00000659527

\section{Araştırmacıların Katkı Oranı Beyanı/ Contribution of Authors}

Araştırma tek bir yazar tarafından yürütülmüştür.

The research was conducted by a single author.

$* * * * * * * *$

\section{Çıkar Çatışması Beyanı / Conflict of Interest}

Çalışma kapsamında herhangi bir kurum veya kişi ile çıkar çatışması bulunmamaktadır.

There is no conflict of interest with any institution or person within the scope of the study.

Intihal Politikası Beyanı / Plagiarism Policy

Bu makale iThenticate yazılımıyla taranmıştır. İntihal tespit edilmemiştir.

This article has been scanned by iThenticate. No plagiarism was detected.

$* * * * * * * *$

Bilimsel Araştırma ve Yayın Etiği Beyanı / Scientific Research and Publication Ethics Statement

Bu çalışmada “Yükseköğretim Kurumları Bilimsel Araștırma ve Yayın Etiği Yönergesi” kapsamında uyulması belirtilen kurallara uyulmuştur.

In this study, the rules stated in the "Higher Education Institutions Scientific Research and Publication Ethics Directive" were followed 